\section{President-elect Bush gets some free advice on science policy}

\section{Washington}

IN AN unprecedented move, the National Academy of Sciences, the National Academy of Engineering and the Institute of Medicine have decided to offer some advice to the new US administration about to occupy the White House, rather than take the more traditional course of waiting until their advice is sought.

The three academies are presenting President-elect George Bush's transition team with four white papers (policy documents) on space policy, AIDS, global environmental change and science advice in the White House. Frank Press, president of the National Academy of Sciences, acknowledges that the transition team is flooded with such documents, but insists that the scientific community has a unique point of view that deserves to be heard.

According to Press, the topics chosen are not the only important ones facing the new administration, but rather reflect projects that have recently been addressed by one or more of the academies. He argues that scientific expertise must be brought to bear on a wide variety of domestic and international issues, and that Bush will need a science adviser with a staff prepared to call attention to topics in crucial need of attention. Otherwise, critical issues may not receive the kind of timely attention they deserve. As an example, Press points to the recent report from the special committee to advise the president on high-temperature superconductivity (see page 105). Although the report is excellent, he says, it, would have had more impact had it been been produced a year ago.

In a campaign speech in October, Bush promised to raise the status of the science adviser to assistant to the president. The white paper urges him to honour that promise. By raising the status of the position, it will be easier to recruit a top scientist to take the job.

One of the first big science decisions facing the new administration will be what to do with the planned space station. Congress has ordered that $\$ 515$ million for the project be held up until May when Bush must announce his plans.

Although the white paper on space

\title{
Administration's 1990 budget proposal
}

THE final budget proposal of the Reagan Administration was sent to Congress on Monday this week as Nature was going to press. As in previous years the President's budget is just a starting point for the budget, as there will undoubtedly be changes both from the new Bush administration and Congress.

The Energy Department total includes a separate line item of $\$ 250$ million for the Superconducting Super Collider which the administration proposes to build in Waxahachie, Texas. The apparent decline in the budgets for the Centers for Disease Control and the National Institutes of Health are explained by the fact that AIDS research now appears as a separate line item for AIDS amounting to $\$ 1,600$ million. In fact, the budget includes a 6.6 per cent increase for basic research budgets. There is also $\$ 100$ million set aside for the human genome project. The NASA budget includes $\$ 2,100$ million for the manned Space Station. There is also $\$ 5,900$ million proposed for the Strategic Defense Initiative.

1989 (estimate) 1990 (proposed) (millions of dollars)

Department of Agriculture

Agricultural Research Service

Cooperative State Research Service

Department of Commerce

National Oceanographic and

Atmospheric Administration

National Institute of Standards and Technology

Department of Energy

Atomic Energy

Defense Activities

General Science and Research Activities

Biological and Environmental Research

Department of Health and Human Services

Centers for Disease Control

National Institutes of Health

Department of Interior

US Geological Survey

Environmental Protection Agency

National Aeronautics and Space Administration (NASA)

National Science Foundation
579

341

1,270

159

8,100

922

269

979

7,147

600

295

1,078

156

9,027

1,169

271

574

6,777

452

3,830

10,969

1,885 policy does not take a position on whether or not the station is a good idea, it urges Bush to maintain a core budget for NASA (National Aeronautics and Space Administration) separate from the space station for a base programme that will "ensure US competence in all space activities". The core budget would include money for launch systems, space science and remote Earth sensing, and support for new technology. Supplemental budgets would cover large projects such as the space station or manned exploration of the Moon or Mars.

The new president will also inherit a pressing need to take steps against the growing problem of AIDS, according to the academies. The disease is expected to cause 200,000 deaths during Bush's fouryear term of office, and there is still no effective therapy. The AIDS white paper spells out specific actions intended to limit the spread of human immunodeficiency virus (HIV), including making effective use of the newly legislated National Commission on AIDS; preventing discrimination against HIV carriers; instituting "aggresssive and unambiguous educational programs" as well as improved surveillance and reporting measures. The administration will also have to address the serious question of how to pay for the increasing costs associated with treating people with AIDS.

Although the AIDS report acknowledges the need for rapid development of new therapeutic agents, it warns against the use of new Food and Drug Administration regulations that permit the distribution of drugs whose effectiveness is still unknown. These new procedures could interfere with the ability to execute "conclusive clinical trials", making it hard to determine whether new drugs actually work as intended.

Finally, the academies suggest that the issue of global environment "must be made more prominent in the scientific, political and foreign policy agendas of the United States". Many federally sponsored activities affect the global environment, and these must be coordinated. The white paper urges the new administration to consider immediate policy changes, such as a reappraisal of nuclear and solar energy and increasing use of the "cleanest" fossil fuels, as strategies to combat global warming. Preservation of rain forests, reduced chlorofluorocarbon emissions and better monitoring of the effects of global warming should all be high on the new president's agenda.

Although he would not be specific, Press says the white papers have been well received by "very senior people" in the new administration. So far, however, the Bush transition team has not announced who will take the science adviser's job, or whether that job will be different from the one that now exists. 